\title{
HUBUNGAN STUNTING DENGAN PERKEMBANGAN MOTORIK KASAR PADA BALITA USIA 6-59 BULAN DI DESA MATARAM ILIR KEC. SEPUTIH SURABAYA KABUPATEN LAMPUNG TENGAH TAHUN 2019
}

\author{
Yesi Nurmalasari ${ }^{1}$, Novaldo Yudhasena², Deviani Utami ${ }^{3}$ \\ ${ }^{1}$ Departemen Ilmu Gizi Medik, Fakultas Kedokteran, Universitas Malahayati \\ ${ }^{2}$ Program Kedokteran, Fakultas Kedokteran, Universitas Malahayati \\ ${ }^{3}$ Departemen Ilmu Kedokteran Komunitas, Fakultas Kedokteran, Universitas \\ Malahayati
}

\begin{abstract}
Corelation of The Stunting Events with The Development of The Age Of 6-59 Months In The Village Mataram Ilir Kec. Seputih Surabaya Central Lampung District 2019. Based on situation data and nutritional analysis in Indonesia in 2017 Toddler nutritional status is measured by index of height per age (TB / $U$ ), height per age (TB / U). The results of the measurement of nutritional status in 2017 with an index of TB / $U$ in infants 0-59 months, get a percentage of short toddlers of $8.6 \%$, and very short at $19.0 \%$. The province with the largest percentage of short and very short toddlers is West Kalimantan (32.5\%) and the lowest is South Sumatra (14.2\%). It was known the relationship between the incidence of stunting and gross motor development in infants aged 6-59 months in Mataram Ilir Village, Kec. Seputih Surabaya Lampung Regency Central Year 2019. Type of quantitative research, analytic survey design with cross sectional approach, population of all infants aged 6-59 months as many as 463 people. A sample of 215 people with a purposive sampling technique. Retrieving data using questionnaire sheets. The data analysis technique uses Chi Square statistical tests. Frequency distribution of stunting in infants, with stunting as many as 106 respondents $(49.3 \%)$. The frequency distribution of gross motor development in infants aged $6-$ 59 months, with an abnormal category of 111 respondents $(51.6 \%)$. The results of the analysis obtained values ( $p$-value $0,000<a 0,05$ ). OR: 18,280. Conclusion, There is a correlation between the incidence of stunting and gross motor development in infants aged 6-59 months.
\end{abstract}

Keywords: Stunting, Rough Motor Development

\begin{abstract}
Abstrak: Hubungan Stunting Dengan Perkembangan Motorik Kasar Pada Balita Usia 6-59 Bulan Di Desa Mataram Ilir Kec. Seputih Surabaya Kabupaten Lampung Tengah Tahun 2019. Berdasarkan data situasi dan analisis gizi di Indonesia pada tahun 2017 Status gizi balita diukur dengan indeks tinggi badan per umur (TB/U), tinggi badan per umur (TB/U). Hasil pengukuran status gizi tahun 2017 dengan indeks TB/U pada balita 0-59 bulan, mendapatkan persentase balita pendek sebesar 8,6\%, dan sangat pendek sebesar 19,0\%. Provinsi dengan persentase balita pendek dan sangat pendek terbesar adalah Kalimantan Barat $(32,5 \%)$ dan terendah adalah Sumatera Selatan (14,2\%). Diketahui hubungan kejadian stunting dengan perkembangan motorik kasar pada balita usia 6-59 bulan di Desa Mataram Ilir Kec. Seputih Surabaya Kabupaten Lampung Tengah Tahun 2019. Jenis penelitian kuantitatif, rancangan survei analitik dengan pendekatan cross sectional, Populasi seluruh balita usia 6-59 bulan sebanyak 463 orang. Sampel sebanyak 215 orang dengan teknik purposive sampling. Pengambilan data menggunakan lembar kuesioner. Teknik analisis data menggunakan uji statistik Chi Square. Distribusi frekuensi kejadian stunting pada balita, dengan kategori mengalami stunting sebanyak 106 responden (49,3\%). Distribusi frekuensi perkembangan motorik kasar pada balita usia 6-59 bulan, dengan kategori tidak normal sebanyak 111 responden $(51,6 \%)$. Hasil analisis diperoleh nilai ( $p$-value
\end{abstract}


$0,000<$ a 0,05). OR: 18,280. Kesimpulanya ada hubungan kejadian stunting dengan perkembangan motorik kasar pada balita usia 6-59 bulan

Kata Kunci: Stunting, Perkembangan Motorik Kasar

\section{PENDAHULUAN}

Berdasarkan data Word Health Organitation (WHO) hampir 11 juta anak di bawah usia lima tahun akan meninggal karena penyebab yang sebagian besar dapat dicegah. Hampir $45 \%$ anak balita di negara berkembang mengalami gangguan dan keterlambatan pertumbuhan dan perkembangan motorik baik motorik kasar gerakan halus sehingga menyebabkan koordinasi, kontrol, dan reaksi hubungan otot-otot menjadi terganggu (World Health Report, 2015).

Berdasarkan data situasi dan analisis gizi di Indonesia pada tahun 2017 Status gizi balita diukur dengan indeks tinggi badan per umur (TB/U), tinggi badan per umur (TB/U). Hasil pengukuran status gizi tahun 2017 dengan indeks TB/U pada balita 0-59 bulan, mendapatkan persentase balita pendek sebesar $8,6 \%$, dan sangat pendek sebesar 19,0\%. Provinsi dengan persentase balita pendek dan sangat pendek terbesar adalah Kalimantan Barat (32,5\%) dan terendah adalah Sumatera Selatan (14,2\%). (Kemenkes RI, 2017).

Berdasarkan data penelitian survei gizi Provinsi Lampung pada tahun 2017 Prevalensi status gizi balita berdasarkan berat badan menurut umur (TB/U) di Provinsi Lampung sebanyak 165.347 balita didapatkan hasil balita persentase balita pendek sebanyak $6,6 \%$ dan balita sangat pendek sebesar $18,2 \%$. Bila dilihat indikator gizi balita berdasarkan Kabupaten Kota di Provinsi Lampung maka terlihat bahwa Kabupaten Lampung Tengah dengan jumlah balita sangat pendek sebanyak $38,6 \%$ dan pendek sebanyak 14,1\% (Dinas Kesehatan Provinsi Lampung, 2017).
Masalah gizi merupakan
masalah multi dimensi yang
dipengaruhi oleh berbagai macam
faktor, seperti faktor ekonomi,
pendidikan, sosial budaya, pertanian
dan kesehatan. mengembangkan suatu bagan penyebab kurang gizi seperti krisis ekonomi, politik, dan sosial merupakan akar masalah nasional dari kejadian kurang gizi. Penyebab langsung permasalahan kurang gizi adalah terjadinya ketidakseimbangan antara asupan makanan yang berkaitan dengan penyakit infeksi. Apabila seseorang kekurangan asupan makanan maka akan menyebabkan daya tahan tubuh menjadi lemah sehingga memudahkan orang tersebut untuk terkena penyakit infeksi (Kemenkes RI, 2011).

Kesehatan bayi dan balita harus dipantau untuk memastikan kesehatan mereka selalu dalam kondisi optimal. Untuk itu dipakai indikator-indikator yang bisa menjadi ukuran keberhasilan upaya peningkatan kesehatan bayi dan balita, salah satu diantaranya adalah pelayanan kesehatan anak balita. Capaian Indikator pelayanan kesehatan anak balita pada tahun 2016 sebesar 75,82\% yang berarti belum mencapai target Renstra pada tahun 2016 yang sebesar $85 \%$. Namun, meningkat dibandingkan tahun 2015 yang sebesar 70,12\%. Capaian indikator menurut provinsi menunjukkan bahwa sebagian besar provinsi di Indonesia memiliki capaian di bawah 85\% (Kemenkes RI, 2017).

Pertumbuhan

dan

perkembangan anak dipengaruhi oleh gizi anak tersebut. Keterlambatan tumbuh kembang merupakan salah satu masalah gizi yang saling terkait antara satu dengan yang lainnya. 
Faktor yang berhubungan dengan status gizi adalah asupan gizi. Pertama, penyebabnya langsung dari status gizi adalah asupan gizi dan penyakit infeksi. Kedua, penyebab tidak langsung, kesediaan pangan tingkat rumah tangga, perilaku/asuhan ibu dan anak, dan pelayanan kesehatan dan lingkungan. Ketiga, masalah utama, yaitu kemiskinan, pendidikan rendah, ketersediaan pangan, dan kesempatan kerja. Keempat, masalah dasar, yaitu krisis politik dan ekonomi (Supariasa, 2012).

Anak yang stunting mengalami pertumbuhan rangka yang lambat dan pendek. Kondisi ini merupakan hasil dari periode panjang akibat tidak terpenuhinya kebutuhan makanan yang meningkatkan kesakitan. Zat gizi memegang peranan penting dalam dua tahun pertama kehidupan. Pertumbuhan dan perkembangan selsel otak memerlukan zat gizi yang adekuat. Kecukupan zat gizi pada masa ini akan mempengaruhi proses tumbuh kembang anak pada periode selanjutnya. Penelitian lain menyatakan bahwa gangguan keterlambatan perkembangan antara lain ditandai dengan lambatnya kematangan sel-sel syaraf, lambatnya gerakan motorik, kurangnya kecerdasan, dan lambatnya respon sosial. Berbagai stimulasi melalui panca indra seperti mendengar, melihat, merasa, mencium, dan meraba, yang diberikan selama awal kehidupan mempunyai pengaruh besar pada pertumbuhan dan maturasi otak (Pantaleon. dkk, 2015). Berdasarkan data sistem pencatatan dan pelaporan tingkat Puskesmas (SP2TP) Puskesmas Seputih Surabaya Kabupaten Lampung Tengah Tahun 2017 didapatkan jumlah balita sebanyak 463 balita.
Prevalensi status gizi balita berdasarkan berat badan menurut umur (TB/U) didapatkan hasil balita persentase balita pendek sebanyak $7,9 \%$ dan balita sangat pendek sebesar $4,2 \%$.

Cakupan deteksi dini tumbuh kembang balita di Puskesmas Bandar Jaya Kabupaten Lampung Tengah pada Tahun 2017 sebesar 75,89\%, dari 526 balita diperiksa terdapat $11,66 \%$ balita mengalami keterlambatan tumbuh kembang.

Tujuan penelitian ini adalah Untuk mengetahui hubungan stunting dengan perkembangan motorik kasar pada anak usia 6-59 bulan di Desa Mataram Ilir Kec. Seputih Surabaya Kabupaten Lampung Tengah Tahun 2019.

\section{METODE}

Jenis penelitian yang digunakan dalam penelitian ini adalah kuantitatif yaitu jenis penelitian yang mencoba mengetahui mengapa masalah kesehatan tersebut bisa terjadi kemudian melakukan analisis hubungannya (Riyanto, 2011).

Populasi dalam penelitian ini seluruh balita usia 6-59 bulan di Desa Mataram Ilir Kec. Seputih Surabaya Kabupaten Lampung Tengah Tahun 2019, sebanyak 463 orang. Sampel sebanyak 215 yang diambil dengan Teknik Purposive Sampling. Rancangan penelitian yang digunakan analitik dengan pendekatan cross sectional, yaitu penelitian yang mempelajari hubungan antara faktor resiko (independen) dan faktor efek (dependen) dimana pengukuran variabel bebas dan variabel terikat sekaligus pada waktu yang sama (Riyanto, 2011). Pengambilan

data menggunakan lembar kuesioner. Teknik analisis data menggunakan uji statistik Chi Square. 
HASIL

\section{Karakteristik Responden}

Tabel 1. Karakteristik Usia Ibu Balita usia 6-59 bulan di Desa Mataram Ilir Kec. Seputih Surabaya Kabupaten Lampung Tengah Tahun 2019

\begin{tabular}{lcc}
\hline Usia ibu & Frekuensi & Persentase \\
\hline$<20$ tahun & 44 & 20,46 \\
$20-35$ tahun & 125 & 58,14 \\
$>35$ tahun & 46 & 21,40 \\
\hline Jumlah & $\mathbf{2 1 5}$ & $\mathbf{1 0 0 , 0 0}$ \\
\hline Pendidikan & Frekuensi & Persentase \\
\hline SD & 76 & 33,35 \\
\hline SMP & 84 & 39,07 \\
\hline SMA & 55 & 25,58 \\
\hline Perguruan Tinggi & - & - \\
\hline Jumlah & $\mathbf{2 1 5}$ & $\mathbf{1 0 0 , 0 0}$ \\
\hline Usia Balita & Frekuensi & Persentase \\
\hline 6-24 bulan & 48 & 22,32 \\
\hline 25-48 bulan & 59 & 27,44 \\
\hline 49-59 bulan & 98 & 45,58 \\
\hline Jumlah & $\mathbf{2 1 5}$ & $\mathbf{1 0 0 , 0 0}$ \\
\hline Jenis kelamin Balita & Frekuensi & Persentase \\
\hline Laki-laki & 91 & 46,98 \\
\hline Perempuan & 114 & 53,02 \\
\hline Jumlah & $\mathbf{2 1 5}$ & $\mathbf{1 0 0 , 0 0}$ \\
\hline
\end{tabular}

Berdasarkan Tabel 1

diketahui bahwa usia ibu yang memiliki anak balita usia 6-59 bulan, sebagian besar adalah usia 20-35 tahun sebanyak 125 responden $(58,14 \%)$. Sebagian besar pendidikan ibu anak balita usia 6-59 bulan, adalah SMP

sebanyak 84 responden $(39,07 \%)$. Usia balita, sebagian besar adalah usia 49-59 bulan sebanyak 98 balita $(45,58 \%)$. Jenis kelamin balita, sebagian besar adalah perempuan sebanyak 114 responden $(53,02 \%)$.

\section{Analisa Univariat}

a. Stunting

Tabel 2. Distribusi frekuensi stunting Pada Anak Balita usia 6-59 bulan di Desa Mataram Ilir Kec. Seputih Surabaya Kabupaten Lampung Tengah Tahun 2019

\begin{tabular}{ccc}
\hline Stunting & Frekuensi & Persentase \\
\hline Tidak mengalami stunting & 109 & 50,7 \\
Mengalami stunting & 106 & 40,3 \\
\hline Jumlah & $\mathbf{2 1 5}$ & $\mathbf{1 0 0 , 0 0}$ \\
\hline
\end{tabular}


Berdasarkan tabel 2 maka dapat diketahui bahwa stunting pada anak balita usia 6-59 bulan, dengan kategori mengalami stunting sebanyak 106 responden (40,3\%).

\begin{tabular}{|c|c|c|}
\hline \multicolumn{3}{|c|}{$\begin{array}{l}\text { b. Perkembangan Motorik Kasar } \\
\text { Tabel 3. Distribusi Frekuensi Perkembangan Motorik Kasar Anak } \\
\text { Usia 6-59 Bulan di Desa Mataram Ilir Kec. Seputih } \\
\text { Surabaya Kabupaten Lampung Tengah Tahun } 2019 \\
\end{array}$} \\
\hline $\begin{array}{c}\text { Perkembangan Motorik } \\
\text { Kasar }\end{array}$ & Frekuensi & Persentase \\
\hline Normal & 104 & 48,4 \\
\hline Tidak normal & 111 & 51,6 \\
\hline Jumlah & 215 & 100,00 \\
\hline $\begin{array}{l}\text { erdasarkan tabel } 3 \text { maka } \\
\text { ketahui bahwa perkembangan } \\
\text { kasar anak usia } 6-59 \text { bulan di } \\
\text { Mataram Ilir Kec. Seputih }\end{array}$ & $\begin{array}{l}\text { Surabaya } \\
\text { Tengah Tah } \\
\text { tidak norma } \\
(51,6 \%)\end{array}$ & $\begin{array}{l}\text { Kabupaten Lampung } \\
\text { un } 2019 \text {, dengan kategori } \\
\text { I sebanyak } 111 \text { responden }\end{array}$ \\
\hline
\end{tabular}

3. Analisa Data Bivariat

a. Hubungan Kejadian Stunting Dengan Perkembangan Motorik Kasar

Tabel. 4 Analisa Hubungan Kejadian Stunting dengan

Perkembangan Motorik kasar Balita usia 6-59 bulan di

Desa Mataram Ilir Kec. Seputih Surabaya Kabupaten

Lampung Tengah Tahun 2019

\begin{tabular}{|c|c|c|c|c|c|c|c|c|}
\hline \multirow{3}{*}{$\begin{array}{l}\text { Kejadian } \\
\text { Stunting }\end{array}$} & \multicolumn{4}{|c|}{$\begin{array}{c}\text { Perkembangan } \\
\text { Motorik Kasar }\end{array}$} & \multirow{2}{*}{\multicolumn{2}{|c|}{ Total }} & \multirow{3}{*}{$\begin{array}{c}p- \\
\text { value }\end{array}$} & \multirow{3}{*}{$\begin{array}{c}\text { OR } \\
(95 \% \mathrm{CI})\end{array}$} \\
\hline & \multicolumn{2}{|c|}{$\begin{array}{c}\text { Tidak } \\
\text { normal } \\
\end{array}$} & \multicolumn{2}{|c|}{ Normal } & & & & \\
\hline & $n$ & $\%$ & $\mathrm{n}$ & $\%$ & $\mathrm{n}$ & $\%$ & & \\
\hline $\begin{array}{l}\text { Mengalami } \\
\text { stunting }\end{array}$ & 88 & 83,0 & 18 & 17,0 & 106 & 100 & & \\
\hline $\begin{array}{c}\text { Tidak } \\
\text { mengalami } \\
\text { stunting }\end{array}$ & 23 & 21,1 & 86 & 78,9 & 109 & 100 & 0,000 & $\begin{array}{c}18,280 \\
(9,218- \\
36,251)\end{array}$ \\
\hline Total & 40 & 47,6 & 44 & 52,4 & 215 & 100 & & \\
\hline
\end{tabular}

Berdasarkan tabel 4 diketahui bahwa dari 106 responden dengan kategori mengalami stunting dan mengalami perkembangan motorik kasar tidak normal sebanyak 88 responden (83\%) dan perkembangan motorik kasar normal sebanyak 18 responden (17\%), sedangkan dari 109 responden dengan kategori tidak mengalami stunting dan perkembangan motorik kasar tidak normal sebanyak 23 responden $(21,1 \%), \quad$ dan perkembangan motorik kasar normal terdapat 86 responden (78,9\%). Hasil uji statistik $p$ value $=0,000$ lebih kecil dari nilai alpha $(\alpha=0,05)$, sehingga terdapat hubungan yang bermakna antara kejadian stunting dengan perkembangan motorik kasar pada balita usia 6-59 bulan di Desa Mataram Ilir Kec. Seputih Surabaya Kabupaten Lampung Tengah Tahun 
2019. Hasil analisis diperoleh nilai OR: 18,280 . Artinya responden yang mengalami stunting berisiko sebesar 18,280 kali anak mengalami gangguan perkembangan motorik kasar dibandingkan anak yang tidak mengalami stunting.

\section{PEMBAHASAN \\ Univariat \\ a. Stunting}

Berdasarkan hasil dari pengolahan data maka dapat diketahui bahwa stunting pada anak balita usia 6-59 bulan di Desa Mataram Ilir Kec. Seputih Surabaya Kabupaten Lampung Tengah Tahun 2019, dengan kategori mengalami stunting sebanyak 106 responden $(49,3 \%)$.

Dampak buruk dari stunting
dalam jangka pendek bisa
menyebabkan terganggunya otak,
kecerdasan, gangguan pertumbuhan
fisik, dan gangguan metabolisme
dalam tubuh. Sedangkan dalam
jangka panjang akibat buruk yang
dapat ditimbulkan adalah menurunnya kemampuan kognitif dan prestasi belajar, menurunnya kekebalan tubuh sehingga mudah sakit, risiko tinggi munculnya penyakit diabetes, kegemukan, penyakit jantung dan pembuluh darah, kanker, stroke dan disabilitas pada usia tua, serta kualitas kerja yang tidak kompetitif yang berakibat pada rendahnya produktifitas ekonomi (Kemenkes RI, 2016).

Gizi dibutuhkan anak untuk pertumbuhan dan perkembangan "energi, berpikir, beraktivitas fisik, dan daya tahan tubuh. Zat gizi yang dibutuhkan anak adalah seluruh zat gizi yang terdiri dari zat gizi makro seperti karbohidrat, protein, lemak, serta zat gizi mikro seperti vitamin dan mineral. Energi adalah kemampuan melakukan usaha dan disebut juga tenaga. Orang yang energik adalah orang yang penuh tenaga sehingga dapat melakukan pekerjaan lebih banyak. Dalam tubuh energi disimpan dalam bentuk cadangan energi, yaitu lemak sebanyak $74 \%$, protein sebanyak $25 \%$ dan karbohidrat $<1 \%$ (Devi, 2012).

Hasil penelitian ini didukung oleh penelitian yang dilakukan Sundari., Nuryanto (2016) tentang hubungan asupan protein, seng, zat besi, dan riwayat penyakit infeksi dengan $z$-score TB/U pada balita di Kelurahan Jangli Kota Semarang. Hasil penelitian diketahui bahwa Sebanyak $36,1 \%$ subjek mengalami stunting. Rerata Z-Score TB/U -1,25 $\pm 1,2$. Rerata asupan protein, seng, dan zat besi subjek berturut-turut $34.8 \pm 13 \mathrm{~g}, 5.2 \pm 2.5 \mathrm{mg}, 8.2 \pm$ $6.5 \mathrm{mg}$ dengan sebagian besar tingkat kecukupan protein, seng, dan zat besi subjek adalah cukup. Sebanyak $29.1 \%$ subjek memiliki riwayat infeksi. Terdapat hubungan antara protein dan penyakit infeksi dengan Z-Score TB/U pada balita.

Berdasarkan hal tersebut peneliti berpendapat bahwa zat gizi diperlukan tubuh untuk melakukan fungsinya, yaitu menghasilkan energi, membangun dan memelihara jaringan, serta mengatur prosesproses kehidupan. kebutuhan dasar gizi atau pangan merupakan salah satu kebutuhan dasar yang utama untuk keperluan kesehatan dan pertumbuhan serta perkembangan bayi/balita. Status gizi kurang terjadi karena tidak terpenuhinya kebutuhan gizi seseorang setiap hari dalam waktu yang lama. Akibat kekurangan gizi pada proses tubuh tergantung pada zat-zat gizi apa yang mengalami kekurangan. Tumbuh kembang bayi dan balita, selain dipengaruhi oleh faktor keturunan juga dipengaruhi oleh faktor lingkungan. Gizi atau nutrisi merupakan salah satu faktor lingkungan dan merupakan penunjang agar proses tumbuh kembang tersebut dapat berjalan dengan memuaskan. Hal ini berarti, pemberian makanan yang berkualitas dan kuantitasnya baik menunjang tumbuh kembang, sehingga bayi dapat tumbuh normal 
dan sehat serta terbebas dari penyakit.

\section{b. Perkembangan Motorik}

Berdasarkan hasil

pengolahan data maka dapat diketahui bahwa perkembangan motorik kasar anak usia 6-59 bulan di Desa Mataram Ilir Kec. Seputih Surabaya Kabupaten Lampung Tengah Tahun 2019, dengan kategori tidak normal sebanyak 111 responden $(51,6 \%)$.

Perkembangan

(development) adalah bertambahnya kemampuan (skill) dalam struktur dan fungsi tubuh yang komplek dalam pola teratur dan dapat diramalkan, sebagai hasil dari proses pematangan/maturitas.

Perkembangan motorik merupakan perkembangan kontrol pergerakan badan melalui koordinasi aktivitas syaraf pusat, saraf tepi dan otot. Kontrol pergerakan ini muncul dari perkembangan refleks-refleks yang dimulai sejak lahir. Anak menjadi tidak berdaya sampai perkembangan ini muncul (Soetjingsih, 2014).

Berdasarkan hal tersebut peneliti berpendapat bahwa tujuan perkembangan motorik adalah mengkaji proses pentahapan kemampuan gerak, apakah kemampuan gerak individu tersebut sudah sesuai dengan masanya. Hal tersebut sangat diperlukan untuk dapat memberi dukungan terhadap terbentuknya kualitas gerak yang proporsioanal pada usianya. Fungsi perkembangan motorik adalah penguasaan keterampilan yang tergambar dalam kemampuan menyelesaikan tugas gerak tertentu. Khualitas gerak terlihat dari seberapa jauh anak tersebut mampu menampilkan tugas gerak yang diberikan dengan tingkat keberhasilan tertentu

\section{Bivariat}

\section{a. Hubungan Stunting Dengan Perkembangan Motorik Kasar} Hasil uji statistik $p$ value $=$ 0,000 lebih kecil dari nilai alpha
( $\alpha=0,05)$, sehingga terdapat hubungan yang bermakna antara kejadian stunting dengan perkembangan motorik kasar pada balita usia 6-59 bulan di Desa Mataram Ilir Kec. Seputih Surabaya Kabupaten Lampung Tengah Tahun 2019. Hasil analisis diperoleh nilai OR: 18,280. Artinya responden yang mengalami stunting berisiko sebesar 18,280 kali anak mengalami gangguan perkembangan motorik kasar yang tidak normal dibandingkan anak yang tidak mengalami stunting.

Kecukupan gizi sangat penting bagi kesehatan balita, dimana seluruh pertumbuhan dan kesehatan balita erat kaitannya dengan masukan makanan yang memadai. Pertumbuhan dan perkembangan yang optimal pada balita memerlukan makanan yang sesuai dengan balita yang sedang tumbuh. Seluruh komponen bangsa, terutama orang tua, harus memperhatikan balita karena balita merupakan generasi penerus dan modal dasar untuk kelangsungan hidup bangsa. Masa balita disebut juga sebagai "golden periode" atau masa keemasan, dimana terbentuk dasar-dasar kemampuan keindraan, berfikir, berbica serta pertumbuhan mental intelektual yang intensif dan awal pertumbuhan moral (Maryunani, 2010).

Tumbuh kembang bayi dan balita, selain dipengaruhi oleh faktor keturunan juga dipengaruhi oleh faktor lingkungan. Gizi atau nutrisi merupakan salah satu faktor lingkungan dan merupakan penunjang agar proses tumbuh kembang tersebut dapat berjalan dengan memuaskan. Hal ini berarti, pemberian makanan yang berkualitas dan kuantitasnya baik menunjang tumbuh kembang, sehingga bayi dapat tumbuh normal dan sehat serta terbebas dari penyakit (Maryunani, 2010). Pertumbuhan

perkembangan anak dipengaruhi oleh gizi anak tersebut. 
Keterlambatan tumbuh kembang merupakan salah satu masalah gizi yang saling terkait antara satu dengan yang lainnya. Faktor yang berhubungan dengan status gizi adalah asupan gizi. Pertama, penyebabnya langsung dari status gizi adalah asupan gizi dan penyakit infeksi. Kedua, penyebab tidak langsung, kesediaan pangan tingkat rumah tangga, perilaku/asuhan ibu dan anak, dan pelayanan kesehatan dan lingkungan. Ketiga, masalah utama, yaitu kemiskinan, pendidikan rendah, ketersediaan pangan, dan kesempatan kerja. Keempat, masalah dasar, yaitu krisis politik dan ekonomi. Pada dasarnya pendidikan merupakan masalah utama yang berhubungan dengan status gizi (Supariasa, 2012). Stunting menjadi permasalahan karena berhubungan dengan meningkatnya risiko terjadinya kesakitan dan kematian, perkembangan otak suboptimal sehingga perkembangan motorik terlambat dan terhambatnya pertumbuhan mental. Beberapa studi menunjukkan risiko yang diakibatkan stunting yaitu penurunan prestasi akademik, meningkatkan risiko obesitas, lebih rentan terhadap penyakit tidak menular dan peningkatan risiko penyakit degeneratif. Oleh karena itu, stunting menjadi prediktor buruknya sumber daya manusia yang selanjutnya akan berpengaruh pada pengembangan potensi bangsa (Sundari \& Nuryanto. 2016).

Dari hasil analisa diketahui bahwa dari 106 responden dengan kategori mengalami stunting dan perkembangan motorik kasar normal sebanyak 18 responden (17\%), hal ini dikarenakan lingkungan pengasuhan anak mendukung perkembangan anak balita tersebut seperti banyak anak balita disekitar tempat tinggal sehingga anak sering bermain dan bersosialisasi dengan baik

Sedangkan dari 109 responden dengan kategori tidak mengalami stunting dan perkembangan motorik kasar tidak normal sebanyak 23 responden $(21,1 \%)$. Hal ini dikarenkan pada anak tersebut pernah menderita penyakit kronis yang menyebabkan terhambatnya perkembangan anak tersebut. Seperti Tuberkulosis dan kelainan jantung bawaan mengakibatkan retardasi pertumbuhan jasmani. Diketahui pula sebagian besar pendidikan ibu dengan kategori rendah, hal ini ini sesuai dengan teori yang menyatakan pendidikan orang tua merupakan salah satu faktor yang penting dalam tumbuh kembang anak. Karena dengan pendidikan yang baik, maka orang tua dapat menerima segala informasi dari luar terutama tentang cara pengasuhan anak yang baik, asupan gizi yang sesuai, sehingga orang tua dapat menjaga kesehatan anaknya, pendidikan dan sebagainya (Cahyaningsih dalam Saputro, 2014).

Pendidikan orang tua merupakan salah satu faktor penting dalam tumbuh kembang anak. Karena dengan pendidikan yang baik orang tua dapat menerima segala informasi dari luar, terutama tentang cara pengasuhan anak yang baik, bagaimana menjaga kesehatan anak, mendidiknya dan sebagainya (Soetjiningsih, 2014).

Hasil penelitian ini sejalan dengan penelitian yang dilakukan Pantaleon, dkk (2015) tentang hubungan Stunting berhubungan dengan perkembangan motorik anak di Kecamatan Sedayu, Bantul, Yogyakarta, dimana diperoleh hasil bahwa sebagian besar perkembangan motorik kasar anak dengan kategori perkembangan abnormal sebanyak (57,5\%). Secara statistik, ada hubungan signifikan antara stunting dengan perkembangan motorik baduta $(p=0,002)$.

Hasil penelitian ini juga didukung penelitian yang dilakukan Ningrum (2017) tentang Hubungan 
Antara Status Gizi Stunting Dan Perkembangan Balita Usia 12-59 Bulan di wilayah Puskesmas Padamara Kabupaten Purbalingga. sebagian besar balita dengan gizi normal memiliki perkembangan normal 31 responden (93,9\%), balita dengan status gizi pendek memliki perkembangan normal sejumlah 25 responden (92,6\%). Hasil uji Fisher exact tes menunjukkan $\mathrm{p}(0,000)<0,05$, artinya ada hubungan antara status gizi dengan perkembangan balita.

Penelitian Pitchik, H. O., Fawzi, W. W., McCoy, D. C., Darling, A. M., Abioye, A. I., Tesha, F., ... \& Sudfeld, C. R. (2018). Tentang Nutrisi prenatal, stimulasi, dan paparan hukuman dikaitkan dengan perkembangan motorik anak dini, kognitif, bahasa, dan perkembangan sosial di Dar Es Salaam Tanzania. Diketahi stimulasi pengasuh dan anak yang lebih besar dikaitkan dengan 0,38 SD, 95\% CI $[0,14,0,63], p$ $<0,01$, skor kognitif / bahasa yang lebih baik. Kelulusan ibu sekolah dasar dikaitkan dengan perkembangan motorik dan kognitif / bahasa yang dilaporkan lebih tinggi. Lebih lanjut, anak-anak dari ibu dengan tinggi $<155 \mathrm{~cm}$ memiliki skor kognitif dan bahasa yang lebih rendah Berdasarkan hal tersebut peneliti berpendapat bahwa stunting bukan merupakan faktor penyebab langsung terjadinya keterlambatan perkembangan, tetapi stunting mempunyai hubungan positif terhadap perkembangan anak balita. Untuk itu disarankan ibu balita agar memberikan makanan beraneka ragam yang berfungsi untuk pertumbuhan dan perkembangan anak balita serta memanfaatkan pelayanan kesehatan seperti mendiskusikan dengan pihak kesehatan jika anak mengalami gangguan perkembangan sehingga diharapkan dapat mencegah terjadinya perkembangan tidak normal pada balita. Tumbuh kembang optimal dapat tercapai apabila ada interaksi antara anak dan orang tua, terutama peranan ibu sangat bermanfaat bagi proses perkembangan anak secara keseluruhan karena orang tua dapat segera mengenali kelainan proses perkembangnya dan sedini mungkin memberikan stimulasi pada tumbuh kembang anak yang menyeluruh dalam aspek fisik, mental, dan sosial. Untuk itu disarankan agar orang tua khususnya ibu balita agar memeriksakan perkembangan balitanya secara rutin pada pelayanan kesehatan, serta dapat berperan aktif dalam memantau tumbuh kembang anak.

\section{KESIMPULAN}

1. Distribusi frekuensi kejadian stunting pada balita di Desa Mataram Ilir Kec. Seputih Surabaya Kabupaten Lampung Tengah Tahun 2019, dengan kategori mengalami stunting sebanyak 106 responden $(49,3 \%)$.

2. Distribusi frekuensi perkembangan motorik kasar pada balita usia 6-59 bulan di Desa Mataram Ilir Kec. Seputih Surabaya Kabupaten Lampung Tengah Tahun 2019, dengan kategori tidak normal sebanyak 111 responden $(51,6 \%)$.

3. Ada hubungan kejadian stunting dengan perkembangan motorik kasar pada balita usia 6-59 bulan di Desa Mataram Ilir Kec. Seputih Surabaya Kabupaten Lampung Tengah Tahun 2019. Hasil analisis diperoleh nilai ( $p$-value $0,000<a$ $0,05)$. OR: 18,280 .

\section{SARAN}

\section{a. Puskesmas Seputih Surabaya}

Disarankan petugas
kesehatan dapat berperan aktif
dalam perencanaan program
peningkatan tumbuh kembang anak,
serta melakukan pemantauan status
gizi balita melalui upaya preventif
dan promotif dengan cara
penyuluhan kesehatan dan memberi
leaflet atau slogan terkait
perkembangan motorik anak dan
stunting.




\section{b. Ibu yang Memiliki Anak Balita}

Disarankan ibu balita agar melakukan stimulasi perkembangan motorik anak serta memberikan makanan beraneka ragam yang berfungsi untuk pertumbuhan dan perkembangan anak balita serta menambah pengetahuan dengan cara menggali informasi dari petugas kesehatan mengenai perkembangan anak balita dan berperan aktif dalam memberikan perhatian yang cukup terhadap perkembangan anak dan aktif membawa anak ke posyandu, melatih dan memantau perkembangan anak.

\section{DAFTAR PUSTAKA}

Adriana, D. (2011). Tumbuh kembang dan terapi bermain pada anak. Jakarta: Salemba Medika.

Kemenkes RI. (2017). Profil Kesehatan Indonesia. Katalog Dalam Terbitan. Jakarta: Kementerian Kesehatan RI.

Kemenkes RI. (2014). Pedoman pelaksanaan stimulasi, deteksi dan intervesi dini tumbuh kembang anak ditingkat pelayanan kesehatan dasar. Katalog Dalam Terbitan. Jendral pembinaan kesehatan masyarakat. Jakarta:

Kementerian Kesehatan RI.

Maryunani, A. (2010). Ilmu kesehatan anak dalam kebidanan. Jakarta: CV. Trans Info Media, 207-223.
Pitchik, H. O., Fawzi, W. W., McCoy, D. C., Darling, A. M., Abioye, A. I., Tesha, F., \& Sudfeld, C. R. (2018). Prenatal nutrition, stimulation, and exposure to punishment are associated with early child motor, cognitive, language, and socioemotional development in Dar es Salaam, Tanzania. Child: care, health and development, 44(6), 841849.

Riyanto, A. (2011). Aplikasi metodologi penelitian kesehatan.

Soetjiningsih. (2014). Tumbuh Kembang Anak. Jakarta: EGC.

Sulistyawati, A. (2014). Deteksi tumbuh kembang anak. Jakarta: Salemba Medika.

Sundari, E., \& Nuryanto, N. (2016). Hubungan Asupan Protein, Seng, Zat Besi, dan Riwayat Penyakit Infeksi dengan ZScore TB/U pada Balita. Journal of Nutrition College, 5(4), 520-529.

Supariasa, I. D. N., Bakri, B., \& Fajar, I. (2012). Penilaian Status Gizi Edisi Revisi. Jakarta: Penerbit Buku Kedokteran ECG.

Wardani, N. I. (2018). Pengaruh Permainan Modifikasi Lari Estafet Terhadap Perkembangan Motorik Kasar Anak Usia 4-5 Tahun

Yuniarti, S. (2015). Asuhan Tumbuh Kembang Neonatus Bayi-Balita dan Anak Pra Sekolah. Bandung: Refika Aditama. 